\section{Evaluation of Salinity Tolerance of Prairie Junegrass, a Potential Low-maintenance Turfgrass Species}

\author{
Sheng Wang and Qi Zhang ${ }^{1}$ \\ Department of Plant Sciences, North Dakota State University, Department \\ \#7670, P.O. Box 6050, Fargo, ND 58108
}

\section{Eric Watkins}

Department of Horticultural Science, University of Minnesota, 1970 Folwell Avenue, St. Paul, MN 55108

Additional index words. Koeleria macrantha, $\mathrm{NaCl}$, germination, dry weight, electrolyte leakage, visual quality

\begin{abstract}
Prairie junegrass (Koeleria macrantha) is a perennial, cool-season, native grass that has shown potential for use as a turfgrass species in the northern Great Plains; however, limited information is available on its salt tolerance. In this study, salinity tolerance of four junegrass populations from North America (Colorado, Minnesota, Nebraska, and North Dakota) and two improved turf-type cultivars from Europe ('Barleria' and 'Barkoel') was evaluated and compared with kentucky bluegrass (Poa pratensis), perennial ryegrass (Lolium perenne), sheep fescue (Festuca ovina), hard fescue $(F$. brevipila), and tall fescue $(F$. arundinacea $)$. Salinity tolerance was determined based on the predicted salinity level causing $50 \%$ reduction of final germination rate (PSLF) and daily germination rate (PSLD) as well as electrolyte leakage (EL), tissue dry weight (DW), and visual quality (VQ) of mature plants. All populations of prairie junegrass showed similar salt tolerance with an average of PSLF and PSLD being 7.1 and $5.3 \mathrm{~g} \cdot \mathrm{L}^{-1}$ $\mathrm{NaCl}$, respectively, comparable to kentucky bluegrass and hard and sheep fescue but lower than tall fescue and perennial ryegrass. Larger variations were observed in $V Q$ in the junegrasses compared with EL and DW, in which 'Barleria' from the European population showed the highest VQ, following two salt-tolerant grasses, tall fescue and sheep fescue. Nebraska population was the least salt-tolerant within the species but still exhibited similar or higher tolerance than kentucky bluegrass and perennial ryegrass cv. Arctic Green. Overall, junegrass was more salt-sensitive during germination but more tolerant to salinity when mature. Salinity tolerance of junegrass may be further improved through turfgrass breeding because salinity tolerance varied in different populations.
\end{abstract}

Prairie junegrass or junegrass (Koeleria macrantha), a cool-season, perennial, shortgrass prairie species, is native to North America (Robertson, 1974). It possesses many characteristics ideal for low-maintenance turfgrass use such as a slow vertical growth rate (Dixon, 2000; Soovali and Bender, 2006), moderate drought tolerance (McKernan et al., 2001), and adaptation to dry and sandy soil (Pammell et al., 1901-1904). Mintenko et al. (2002) evaluated 28 native grasses, including an improved turf-type prairie junegrass ('Barkoel') from Europe and three prairie junegrass populations collected from Alberta, Iran, and Minnesota. 'Barkoel' junegrass yielded some of the highest quality

\footnotetext{
Received for publication 24 Jan. 2011. Accepted for publication 15 May 2011.

This research was supported in part by Hatch Project ND01540 and the NDSU Development Foundation.

We thank Drs. A. Zuk and H. Hatterman-Valenti for their critical review of the manuscript.

${ }^{1}$ To whom reprint requests should be addressed; e-mail qi.zhang.1@ndsu.edu.
}

ratings and the populations from Alberta and Minnesota were among the grasses with the earliest spring green-up in the study. Clark and Watkins (2010b) reported that 30 of 48 prairie junegrass accessions provided adequate turf quality (5.0 or greater) after a 3year mowed spaced plant field evaluation under low-input conditions in St. Paul, MN. Furthermore, prairie junegrass has the potential to produce sufficient seeds to be economically available for the turf industry (Clark and Watkins, 2010a), a major limiting factor causing reduced application of buffalograss (Buchloe dactyloides), another native grass with similar ideal characteristics of xeriscaphytic turf (Riordan and Browning, 2003).

Low-input turfgrass must meet visual and functional requirement under minimum care. Salinity is a major stress that reduces turf appearance and inhibits plant growth in the Great Plains. For instance, high soil sodium and salinity affects $1,900,000$ and 700,000 acres of land in North Dakota, respectively (Seelig, 2000). One of the most common methods to address salt damage is use of species and cultivars that exhibit salinity tolerance. Mintenko and Smith (2001) reported prairie junegrass was tolerant to moderate soil salinity levels (4 to $8 \mathrm{dS} \cdot \mathrm{m}^{-1}$ ) at maturity but more sensitive to salinity during germination; however, 'Barkoel' was the only cultivar evaluated in their study. Large variations have been reported in the characteristics of seed production and turf quality in prairie junegrass germplasm (Clark and Watkins, 2010a, 2010b). Therefore, the objective of this study was to evaluate relative salinity tolerance of four native prairie junegrass populations (Colorado, Minnesota, Nebraska, and North Dakota) along with the European cvs. Barleria and Barkoel and then compare their performance with several commonly used coolseason turfgrass species. These results can then be used by turfgrass breeders in germplasm improvement programs aimed at developing salt-tolerant low-input turfgrass cultivars.

\section{Materials and Methods}

Plant material. Five populations of junegrass, one tall fescue, one sheep fescue, one hard fescue, one perennial ryegrass, and two kentucky bluegrasses were used in this study (Table 1). The North American junegrass germplasm was collected from Colorado (Weld county), Minnesota (Wabasha county), Nebraska (Sioux and Dawes counties), and North Dakota (Billings county) as seed from native stands in either 2005 or 2006. Plants were grown from seed and placed into a breeding nursery after the collection. Each breeding nursery contained only germplasm collected from one state to avoid outcrossing with germplasm from different collection areas. Seed from these nurseries was harvested and bulked and labeled as Colorado, Minnesota, and Nebraska populations. Material representing the North Dakota population was harvested from a single plant originated from seed collected in Billings county, ND. This single plant was representative of the entire population because the population exhibited uniformity in both unmowed nurseries and mowed turf evaluations. Seeds of 'Barkoel' and 'Barleria', the European population, were provided by Barenbrug USA.

The sheep fescue used in this study is a selection developed at the University of Minnesota for use on roadsides in cold climates where salinity stress is problematic. The hard fescue is an advanced population from the University of Minnesota breeding program that has been selected for use as lowinput turf in Minnesota; however, it has not been screened for salinity tolerance. 'Arctic Green' perennial ryegrass was released by the University of Minnesota in 2008 for improved winter-hardiness and crown rust resistance. Other cultivars and selections were identified based on their performance (i.e., acceptable quality under low-maintenance management) in turfgrass trials in Minnesota and/or North Dakota.

Seed germination. Seeds of the grasses were surface-sterilized following the method of Wang and Zhang (2010). Seeds were submerged in $70 \%$ ethanol for $1 \mathrm{~min}$ followed by submersion in $2 \%$ sodium hypochlorite solution 
for $20 \mathrm{~min}$. Seeds were then rinsed three times with deionized/distilled water $\left(\mathrm{ddH}_{2} \mathrm{O}\right)$ and air-dried in a laminar-flow hood. Thirtysix seeds of each grass were placed in a $100 \times$ $15-\mathrm{mm}$ petri dish containing $20 \mathrm{~mL}$ of $1 \%$ agar salinized with $0,5,10,15$, or $20 \mathrm{~g} \cdot \mathrm{L}^{-1}$ $\mathrm{NaCl}$ and the electrical conductivity (EC) levels of the salt solutions were 0.0, 8.6, $15.3,20.4$, and $25.7 \mathrm{dS} \cdot \mathrm{m}^{-1}$, respectively, when measured with an EC meter (Model 1054; VWR International LLC, West Chester, PA). Petri dishes were placed in an incubator (Model I-35 VL; Percival Scientific, Perry, IA) at $20 / 15{ }^{\circ} \mathrm{C}$ (day/night) under fluorescent light $\left(36 \mu \mathrm{mol} \cdot \mathrm{s}^{-1} \cdot \mathrm{m}^{-2}\right)$ with a $15 / 9$-h (light/ dark) photoperiod for $30 \mathrm{~d}$ (Mintenko and Smith, 2001).

This experiment was conducted in a completely randomized design consisting of three replications of a 12 (grass) $\times 5$ (salinity level) factorial arrangement. The number of seeds germinating per dish was recorded three times a week. Seed germination was defined as an emerged shoot visible under $2 \times$ magnification (McCarty and Dudeck, 1993). Final germination rate (FGR) and daily germination rate (DGR) were calculated using FGR $(\%)=$ $100 \times\left[\left(\sum n\right) / 36\right]$ and $\operatorname{DGR}(\% / \mathrm{d})=100 \times$ $[(n / D)] / 36$, where $n$ was the number of new seeds germinated at each counting and $D$ was the number of days accumulated up to that counting (Wang and Zhang, 2010). To avoid the differences that may be attributed by seed size or seedling vigor, FGR was standardized by calculating as a percentage of the control iment was conducted from 29 Jan. to 1 Mar. (Study I) and repeated from 9 Apr. to 10 May 2010 (Study II). Final germination rate and DGR were transformed using arcsine and square root, respectively, before the analysis of variance. All data were subjected to PROC GLM (SAS, 2004) and means were separated with Fisher's protected least significant difference at $P \leq 0.05$. Regression analyses within each grass were conducted to predict salinity levels, which caused $50 \%$ reduction in FGR and DGR. The salinity tolerance was expressed as the predicted salinity level causing $50 \%$ reduction of FGR (PSLF) and the predicted salinity level causing $50 \%$ reduction of DGR (PSLD) (Zhang et al., 2011). value (Horst and Dunning, 1989). The exper-

Vegetative growth. Thirty plugs $(5 \times 5 \mathrm{~cm})$ of each grass initiated from a single seed were transplanted into D20 deepots ( $8 \mathrm{~cm}$-diam., 20 cm-deep; Stuewe and Sons, Inc., Tangent, OR) with Miracle-Gro potting mix (Scotts Company LLC, Marysville, OH) on 15 July 2009. Grasses were mowed at $5 \mathrm{~cm}$ once a week and hand-watered every other day until water drained freely from the bottom. Fertilizer (13.0N-0.0P-22.0K; Anderson Golf Products, Maumee, $\mathrm{OH}$ ) was applied at $12.5 \mathrm{~kg} \cdot \mathrm{ha}^{-1} \mathrm{~N}$ once each month. Grasses were exposed to saline conditions after a 3-month establishment period in the greenhouse. Saline conditions were comprised of $\mathrm{NaCl}$ at $0,5,10,15$, or $20 \mathrm{~g} \cdot \mathrm{L}^{-1}$ dissolved in tap water with EC at 1.3, $9.8,16.3,22.3$, or $27.5 \mathrm{dS} \cdot \mathrm{m}^{-1}$, respectively. Grasses were soaked in the salt solution one time each week in a 30 -L tank $(59 \times 47 \times 39$ $\mathrm{cm})$ for $2 \mathrm{~h}$ and then drained freely. The tank was refilled with the fresh solution of the same concentration after each soaking. No additional irrigation was applied to the plants and no drought stress symptom (i.e., leaf wilting) was observed between each soaking.

The experiment was arranged in a splitplot design with salinity level being the whole-plot factor (arranged in a randomized complete block design with three replicates) and grass being the subplot factor. Data were collected on tissue EL, DW, and VQ at 2 and 5 weeks after treatment (WAT). Electrolyte leakage was measured following the method of $\mathrm{Su}$ et al. (2007). Briefly, five fully expanded leaves were collected from each container and rinsed three times with $\mathrm{ddH}_{2} \mathrm{O}$. The leaves were then cut into $\approx 2$-cm segments and placed in a test tube containing 20

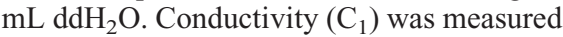
with an EC meter after the test tubes were agitated on a shaker (Model 6010; Eberbach Corp., Ann Arbor, MI) for 24 h. The leaf samples were then autoclaved at $121{ }^{\circ} \mathrm{C}$ for $20 \mathrm{~min}$ and the test tubes were agitated for another $24 \mathrm{~h}$ followed by a second conductivity measurement $\left(\mathrm{C}_{2}\right)$. Electrolyte leakage (\%) was calculated as $\mathrm{EL}=\mathrm{C}_{1} / \mathrm{C}_{2} \times 100$ with lower EL indicating a higher tolerance to stresses. Tissue DW was recorded after the clippings were oven-dried at $60{ }^{\circ} \mathrm{C}$ for $48 \mathrm{~h}$. Tissue EL and DW of each grass under saline conditions were expressed as a percentage of

Table 1 . Predicted salinity levels $\left(\mathrm{g} \cdot \mathrm{L}^{-1} \mathrm{NaCl}\right)$ causing $50 \%$ reduction in final germination rate and daily germination rate in prairie junegrass and other cool-season turfgrasses.

\begin{tabular}{lcc}
\hline Grass & PSLF $^{z}\left(\mathrm{~g} \cdot \mathrm{L}^{-1} \mathrm{NaCl}\right)$ & PSLD $\left(\mathrm{g} \cdot \mathrm{L}^{-1} \mathrm{NaCl}\right)$ \\
\hline Tall fescue-'Falcon IV' & $14.7 \mathrm{a}^{\mathrm{y}}$ & $10.8 \mathrm{a}$ \\
Perennial ryegrass-'Arctic Green' & $13.3 \mathrm{a}$ & $9.8 \mathrm{a}$ \\
Hard fescue-'MN-HD1' & $8.9 \mathrm{~b}$ & $6.2 \mathrm{~b}$ \\
Prairie junegrass-'Barkoel' & $8.6 \mathrm{bc}$ & $5.2 \mathrm{bc}$ \\
Prairie junegrass-'Barleria' & $7.9 \mathrm{bcd}$ & $6.6 \mathrm{~b}$ \\
Kentucky bluegrass-'Langara' & $7.6 \mathrm{bcd}$ & $5.4 \mathrm{bc}$ \\
Prairie junegrass-North Dakota & $7.6 \mathrm{bcd}$ & $4.2 \mathrm{c}$ \\
Sheep fescue-'67135' & $7.6 \mathrm{bcd}$ & $4.2 \mathrm{c}$ \\
Kentucky bluegrass-'Park' & $7.2 \mathrm{bcd}$ & $5.1 \mathrm{bc}$ \\
Prairie junegrass-Minnesota & $6.6 \mathrm{cde}$ & $5.3 \mathrm{bc}$ \\
Prairie junegrass-Nebraska & $6.6 \mathrm{de}$ & $4.9 \mathrm{bc}$ \\
Prairie junegrass-Colorado & $5.5 \mathrm{e}$ & $5.5 \mathrm{bc}$ \\
\hline${ }^{2}$ PSLF = the predicted salinity level causing 50\% reduction of final germination rate; PSLD $=$ the predicted \\
salinity level causing 50\% reduction of daily germination rate. \\
'Means in each column followed by the same letter are not significantly different at the $P \leq 0.05$ level.
\end{tabular}

the control value of the same grass to minimize the difference attributed to variable growing habits in different species (Horst and Beadle, 1984). Visual quality was evaluated with a 1 to 9 scale, in which $1=$ dead grass, $5=$ acceptable, and $9=$ best quality based on color, texture, and uniformity (Emmons, 2000). The experiment was conducted from 10 Mar. to 14 Apr. (Study I) and repeated from 17 May to 21 June 2010 (Study II). Salinity levels were reduced to $0,3,6,9$, or $12 \mathrm{~g} \cdot \mathrm{L}^{-1}$ of $\mathrm{NaCl}(\mathrm{EC}=1.3,6.5,10.7,14.8$, or $18.5 \mathrm{dS} \cdot \mathrm{m}^{-1}$, respectively) in Study II as a result of a rapid DW decline at the highest saline level $\left(20 \mathrm{~g} \cdot \mathrm{L}^{-1}\right)$ observed during Study I. Data were subjected to PROC GLM (SAS, 2004) and means were separated with Fisher's protected least significant difference at $P \leq$ 0.05 . PROC CORR was applied to evaluate the relationships among EL, DW, and VQ.

\section{Results}

Seed germination. Statistical analysis showed that Studies I and II were homogeneous (data not shown); thus, the results were combined before the analyses of variance and regression. Salinity had an adverse effect on FGR and DGR when data were pooled across grasses (Fig. 1). Final germination rate was reduced from $100 \%$ in the control treatment to $76 \%, 25 \%, 11 \%$, and $3 \%$ as salinity increased from 5 to 10,15 , and 20 $\mathrm{g} \cdot \mathrm{L}^{-1} \mathrm{NaCl}$, respectively (Fig. 1A). Similarly,
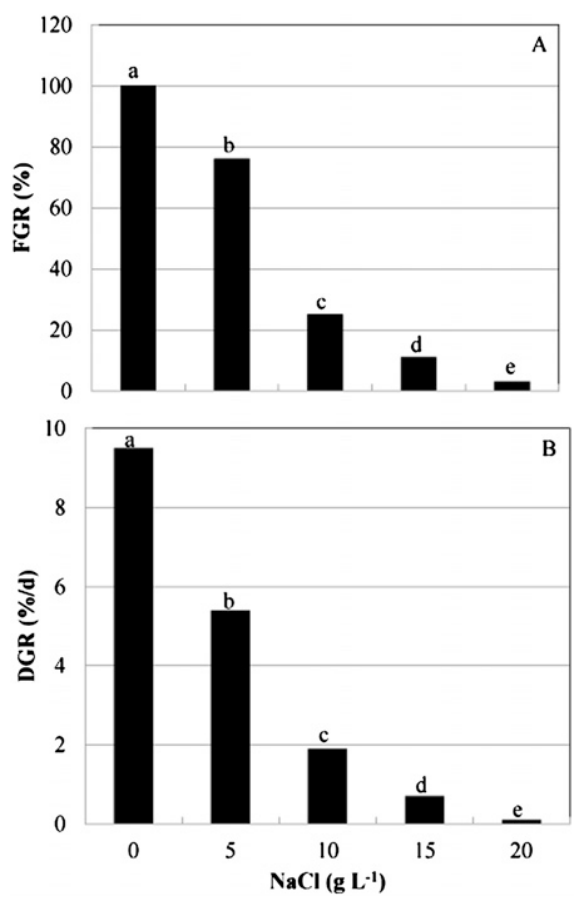

Fig. 1. Final germination rate (FGR, \%) (A) and daily germination rate (DGR, \%/d) (B) across all grasses as affected by salinity. Means followed by the same letter are not significantly different at the $P \leq 0.05$ level. Final germination rate under saline conditions was standardized by calculated as a percentage of the control $\left(\mathrm{NaCl}=0 \mathrm{~g} \cdot \mathrm{L}^{-1}\right)$. 
DGR was reduced from $9.5 \%$ d to $5.4(43 \%$ reduction), $1.9(80 \%), 0.7(93 \%)$, and $0.1 \%$ / d (99\%) at the same saline levels (Fig. 1B).

Tall fescue and perennial ryegrass had the highest PSLF when data were pooled across saline levels (14.7 and $13.3 \mathrm{~g} \cdot \mathrm{L}^{-1} \mathrm{NaCl}$, respectively), whereas other grasses required lower saline levels, ranging from 8.9 to 5.5 $\mathrm{g} \cdot \mathrm{L}^{-1} \mathrm{NaCl}$ to cause $50 \%$ reduction in FGR (Table 1). Within prairie junegrasses, 'Barkoel' had the highest PSLF $\left(8.6 \mathrm{~g} \cdot \mathrm{L}^{-1}\right), 36 \%$ higher than that of Colorado population (5.5 $\mathrm{g} \cdot \mathrm{L}^{-1}$ ) (Table 1). Regression analysis showed that tall fescue and perennial ryegrass required similar saline levels to reduce DGR by $50 \%$, indicating their similar tolerance to salt stress (Table 1). An average saline level of $5.3 \mathrm{~g} \cdot \mathrm{L}^{-1} \mathrm{NaCl}$ was required to cause $50 \%$ reduction in DGR in other grasses, which was $51 \%$ or $46 \%$ lower than that of tall fescue or perennial ryegrass, respectively (Table 1). Similarly, significant differences in PSLD were observed between prairie junegrass entries with 'Barleria' and the population of North Dakota being the most salt-tolerant and salt-sensitive, respectively (Table 1).

Vegetative growth. The results of the two studies are presented separately as salt levels varied. Significant differences in EL, DW, and VQ of both grasses and salinity levels were observed. However, the interaction between grass and saline level was only significant for VQ in both studies (data not shown).

Leaf electrolyte leakage. Electrolyte leakage significantly increased by $61 \%, 160 \%$, $200 \%$, and $291 \%$ when salinity raised from 0 to $5,10,15$, and $20 \mathrm{~g} \cdot \mathrm{L}^{-1}$, respectively, at 2 WAT in Study I (Fig. 2I). By 5 WAT, EL in the grasses exposed to the highest saline level $\left(20 \mathrm{~g} \cdot \mathrm{L}^{-1}\right)$ reached $1119 \%$ (Fig. 2I). Similarly, EL was elevated as the saline level increased and saline stress progressed in Study II (Fig. 2IV). Among all of the grasses, tall fescue had the lowest EL in both studies, except 5 WAT in Study I (Table 2), indicating its higher salt tolerance. In Study I, junegrass population of Minnesota was the most salt-sensitive grass with the highest EL at 2 and 5 WAT, whereas 'Barleria' junegrass showed significantly high EL at 5 WAT (Table 2). In Study II, 'Park' kentucky bluegrass and 'Barkoel' prairie junegrass had the highest EL at 2 and 5 WAT, respectively (Table 2).

Leaf dry weight. Leaf DW was significantly reduced when the saline level was higher than 5 and $6 \mathrm{~g} \cdot \mathrm{L}^{-1} \mathrm{NaCl}$ in Studies I and II, respectively, at 2 WAT when data were pooled across the grasses (Fig. 2II, V). At 5 WAT, DW in all treatments, excluding the $5 \mathrm{~g} \cdot \mathrm{L}^{-1} \mathrm{NaCl}$ treatment in Study I and 3 $\mathrm{g} \cdot \mathrm{L}^{-1}$ in Study II, dropped to less than $50 \%$ of the control. Tissue DW was reduced to less than $10 \%$ of the control at 5 WAT when the salinity was higher than 9 to $10 \mathrm{~g} \cdot \mathrm{L}^{-1}$ (Fig. 2II, V). Significant differences in DW were observed in the grasses in Study I. 'Barleria' and 'Barkoel', the two European prairie junegrass cultivars, had the highest DW at 2 WAT followed by sheep and hard fescue (Table 3). However, hard fescue had the highest DW by
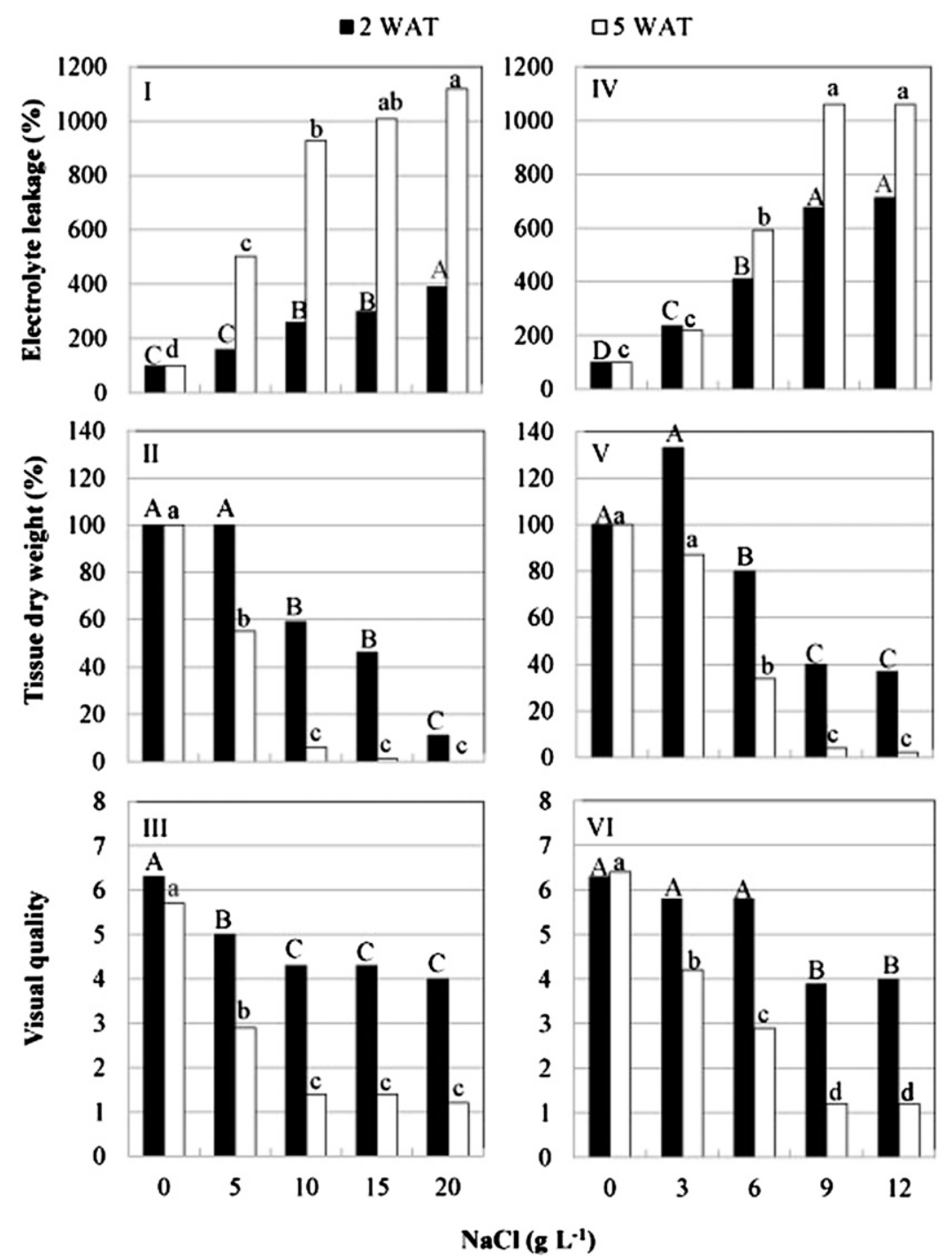

Fig. 2. Salinity effects on electrolyte leakage (\%), tissue dry weight (\%), and visual quality across all grasses in Study I (I-III) and Study II (IV-VI). Electrolyte leakage and tissue dry weight under saline conditions were expressed as a percentage of the control $\left(\mathrm{NaCl}=0 \mathrm{~g} \cdot \mathrm{L}^{-1}\right)$. Upper and lower case letters represented significant differences at $P \leq 0.05$ level for 2 and 5 weeks after treatment (WAT), respectively.

Table 2. Electrolyte leakage in prairie junegrass and other cool-season turfgrasses across all salinity levels at 2 and 5 weeks after treatment (WAT).

\begin{tabular}{|c|c|c|c|c|}
\hline \multirow[b]{2}{*}{ Grass } & \multicolumn{2}{|c|}{ Study I ${ }^{\mathrm{z}}$} & \multicolumn{2}{|c|}{ Study II } \\
\hline & 2 WAT & 5 WAT & 2 WAT & 5 WAT \\
\hline Tall fescue-'Falcon IV' & $165 \mathrm{c}^{\mathrm{y}, \mathrm{x}}$ & $776 \mathrm{abc}$ & $322 \mathrm{~d}$ & $396 \mathrm{c}$ \\
\hline Hard fescue-'MN-HD1' & $187 \mathrm{c}$ & $770 \mathrm{abc}$ & $317 \mathrm{~d}$ & $660 \mathrm{~b}$ \\
\hline Sheep fescue-' 67135 ’ & $206 \mathrm{bc}$ & $547 \mathrm{c}$ & $365 \mathrm{~cd}$ & $419 \mathrm{bc}$ \\
\hline Prairie junegrass - 'Barleria' & $212 \mathrm{bc}$ & 864 a & $364 \mathrm{~cd}$ & $399 \mathrm{bc}$ \\
\hline Prairie junegrass_-'Barkoel' & $230 \mathrm{bc}$ & $606 \mathrm{bc}$ & $431 \mathrm{bcd}$ & $961 \mathrm{a}$ \\
\hline Kentucky bluegrass - 'Langara' & $234 \mathrm{bc}$ & $834 \mathrm{ab}$ & $366 \mathrm{~cd}$ & $639 \mathrm{~b}$ \\
\hline Prairie junegrass - Colorado & $242 \mathrm{bc}$ & $688 \mathrm{abc}$ & $425 \mathrm{bcd}$ & $677 \mathrm{~b}$ \\
\hline Kentucky bluegrass_-'Park' & $243 \mathrm{bc}$ & $614 \mathrm{bc}$ & $755 \mathrm{a}$ & $737 \mathrm{ab}$ \\
\hline Prairie junegrass - North Dakota & $252 \mathrm{bc}$ & $784 \mathrm{ab}$ & $358 \mathrm{~cd}$ & $591 \mathrm{bc}$ \\
\hline Perennial ryegrass - 'Arctic Green' & $253 \mathrm{bc}$ & $674 \mathrm{abc}$ & $544 \mathrm{~b}$ & $597 \mathrm{bc}$ \\
\hline Prairie junegrass-Nebraska & $295 \mathrm{ab}$ & $832 \mathrm{ab}$ & $519 \mathrm{bc}$ & $767 \mathrm{ab}$ \\
\hline Prairie junegrass-Minnesota & $387 \mathrm{a}$ & $898 \mathrm{a}$ & $363 \mathrm{~cd}$ & $586 \mathrm{bc}$ \\
\hline
\end{tabular}

${ }^{\mathrm{z}}$ Saline levels were $0,5,10,15$, and $20 \mathrm{NaCl} \mathrm{g} \cdot \mathrm{L}^{-1}$ in Study I and $0,3,6,9$, and $12 \mathrm{NaCl} \mathrm{g} \cdot \mathrm{L}^{-1}$ in Study II. ${ }^{y}$ Data under saline conditions were expressed as a percentage of the control $\left(\mathrm{NaCl}=0 \mathrm{~g} \cdot \mathrm{L}^{-1}\right)$.

${ }^{x}$ Means in each column followed by the same letter are not significantly different at the $P \leq 0.05$ level.

5 WAT in Study I and it was the only grass with DW higher than $50 \%$ of control. In Study II, no significant difference in DW of all grasses at both 2 and 5 WAT was observed (Table 3), which may be a result of the reduced salinity levels applied. 
Visual quality. When data were pooled across the grasses, no adequate quality (quality 5.0 or greater) was observed at salinity levels higher than 5 and $6 \mathrm{~g} \cdot \mathrm{L}^{-1}$ at 2 WAT in Study I and Study II, respectively (Fig. 2III, VI). All grasses under saline conditions showed a poor appearance by 5 WAT in both studies (Fig. 2III, VI). Tall fescue, sheep fescue, hard fescue, and 'Barleria' prairie junegrass showed acceptable performance (i.e., the grass materials were able to survive and provided acceptable quality under regular mowing conditions) at 2 WAT in Study I when data were pooled across salinity levels (Table 4). As saline conditions extended, all grasses in Study I exhibited VQ ratings less than 5.0 at 5 WAT. Seven grasses had acceptable quality at 2 WAT in Study II compared with four grasses in Study I, which may be the result of the reduced saline levels in Study II. However, similar to Study I, no grasses showed adequate appearance (quality greater than 5.0) at 5 WAT in Study II. Significant interactions between salinity level and grass entry were observed in VQ on all sampling dates, except 2 WAT in Study I (Fig. 3).

\section{Discussion}

Salinity reduced FGR and DGR; however, its impact is greater on DGR than on FGR because higher reduction rate was observed on DGR at low saline levels (Fig. 1). Furthermore, PSLD of all grasses was lower than PSLF, except of prairie junegrassColorado (Table 1). Similar results were reported by Dai et al. (2009) and Wang and Zhang (2010). Therefore, DGR and PSLD can be used as more sensitive indicators of relative saline tolerance during germination than FGR and PSLF with higher DGR and PSLD suggesting higher tolerance.

Electrolyte leakage (an indicator of cell membrane stability) and tissue DW (or yield) (an indicator of overall vigor) have been widely used for screening tolerance of drought-related stresses in plants, including sorghum (Sorghum bicolor) (Sullivan and Ross, 1979), wheat (Triticum aestivum) (Blum and Ebrecon, 1981), tomato (Lycopersicon esculentum) (Chen et al., 1982), and turfgrass (Marcum, 1998; Su et al., 2007). Under salinity stress, plants are not only exposed to ion toxicity and imbalance, but also water deficiencies that are the most common and serious consequences of salt stress (Munns, 2002; TabaeiAghdaei et al., 2000). Marcum (2001) evaluated the salinity tolerance of 35 bentgrass cultivars and reported that tissue dry weight (root or shoot) was an effective parameter for predicting salinity tolerance along with percentage of green leaf area and root length. Farooq and Azam (2006) reported significant correlations between EL and salt stress injury (relative water content, $\mathrm{Na}^{+}$and $\mathrm{K}^{+}$leaf content, and yield) in wheat; thus, EL is also a reliable technique for screening salt tolerance. Turfgrass with high stress tolerance must demonstrate not only functional quality, but also visual quality. Mintenko and Smith (2001) suggested that visual quality was more
Table 3. Tissue dry weight in prairie junegrass and other cool-season turfgrasses across all salinity levels at 2 and 5 weeks after treatment (WAT).

\begin{tabular}{|c|c|c|c|c|}
\hline \multirow[b]{2}{*}{ Grass } & \multicolumn{2}{|c|}{ Study Iz } & \multicolumn{2}{|c|}{ Study II } \\
\hline & $\overline{2 \mathrm{WAT}}$ & $\overline{5 \mathrm{WAT}}$ & $2 \mathrm{WAT}$ & 5 WAT \\
\hline Prairie junegrass-'Barleria' & $97 \mathrm{a}^{\mathrm{y}, \mathrm{x}}$ & $37 \mathrm{~b}$ & $139 \mathrm{a}$ & $56 \mathrm{a}$ \\
\hline Prairie junegrass-'Barkoel' & $95 \mathrm{a}$ & $27 \mathrm{bc}$ & $96 \mathrm{a}$ & $35 \mathrm{a}$ \\
\hline Sheep fescue- ' 67135 ' & $86 \mathrm{ab}$ & $59 \mathrm{a}$ & $66 \mathrm{a}$ & $66 \mathrm{a}$ \\
\hline Hard fescue-'MN-HD1' & $75 a b c$ & $35 \mathrm{~b}$ & $71 \mathrm{a}$ & $47 \mathrm{a}$ \\
\hline Kentucky bluegrass-'Langara' & $66 \mathrm{bcd}$ & $32 \mathrm{bc}$ & $74 \mathrm{a}$ & $37 \mathrm{a}$ \\
\hline Perennial ryegrass-'Arctic Green' & 61 bcde & $31 \mathrm{bc}$ & $83 \mathrm{a}$ & $44 \mathrm{a}$ \\
\hline Kentucky bluegrass-'Park' & $56 \mathrm{cde}$ & $34 \mathrm{bc}$ & $92 \mathrm{a}$ & $55 \mathrm{a}$ \\
\hline Tall fescue-'Falcon IV' & $54 \mathrm{cde}$ & $34 \mathrm{bc}$ & $73 \mathrm{a}$ & $53 \mathrm{a}$ \\
\hline Prairie junegrass - Nebraska & $47 \mathrm{cde}$ & $23 \mathrm{bc}$ & $60 \mathrm{a}$ & $34 \mathrm{a}$ \\
\hline Prairie junegrass - Colorado & $45 \mathrm{de}$ & $28 \mathrm{bc}$ & $66 \mathrm{a}$ & $36 \mathrm{a}$ \\
\hline Prairie junegrass-Minnesota & 42 de & $25 \mathrm{bc}$ & $64 \mathrm{a}$ & $34 \mathrm{a}$ \\
\hline Prairie junegrass-North Dakota & $33 \mathrm{e}$ & $20 \mathrm{c}$ & $49 \mathrm{a}$ & $45 \mathrm{a}$ \\
\hline
\end{tabular}

${ }^{{ }^{2}}$ Saline levels were $0,5,10,15$, and $20 \mathrm{NaCl} \mathrm{g} \cdot \mathrm{L}^{-1}$ in Study I and 0, 3, 6, 9, and $12 \mathrm{NaCl} \mathrm{g} \cdot \mathrm{L}^{-1}$ in Study II. ${ }^{y}$ Data under saline conditions were expressed as a percentage of the control $\left(\mathrm{NaCl}=0 \mathrm{~g} \cdot \mathrm{L}^{-1}\right)$.

${ }^{x}$ Means in each column followed by the same letter are not significantly different at the $P \leq 0.05$ level.

Table 4. Visual quality in prairie junegrass and other cool-season turfgrasses across all salinity levels at 2 and 5 weeks after treatment (WAT).

\begin{tabular}{|c|c|c|c|c|}
\hline \multirow[b]{2}{*}{ Grass } & \multicolumn{2}{|c|}{ Study $\mathrm{I}^{\mathrm{z}}$} & \multicolumn{2}{|c|}{ Study II } \\
\hline & $2 \mathrm{WAT}$ & $5 \mathrm{WAT}$ & $\overline{2 \mathrm{WAT}}$ & $5 \mathrm{WAT}$ \\
\hline Tall fescue-'Falcon IV' & $5.73 \mathrm{a}^{\mathrm{y}}$ & $3.60 \mathrm{a}$ & $6.33 \mathrm{a}$ & $4.60 \mathrm{a}$ \\
\hline Sheep fescue-' 67135 ' & $5.67 \mathrm{a}$ & $2.87 \mathrm{bc}$ & $5.40 \mathrm{~cd}$ & $3.73 \mathrm{~b}$ \\
\hline Hard fescue-'MN-HD1' & $5.60 \mathrm{a}$ & $3.00 \mathrm{~b}$ & $4.47 \mathrm{efg}$ & $2.67 \mathrm{ef}$ \\
\hline Prairie junegrass_-'Barleria' & $5.40 \mathrm{ab}$ & $2.93 \mathrm{bc}$ & $5.67 \mathrm{~b}$ & $3.27 \mathrm{~cd}$ \\
\hline Prairie junegrass - 'Barkoel' & $4.87 \mathrm{bcd}$ & $2.53 \mathrm{~cd}$ & $5.67 \mathrm{~b}$ & $3.47 \mathrm{bc}$ \\
\hline Prairie junegrass - Colorado & $4.93 \mathrm{bc}$ & $2.53 \mathrm{~cd}$ & $5.67 \mathrm{bc}$ & $3.07 \mathrm{cde}$ \\
\hline Prairie junegrass-North Dakota & $4.73 \mathrm{~cd}$ & $2.07 \mathrm{e}$ & $5.08 \mathrm{~cd}$ & $3.01 \mathrm{cdef}$ \\
\hline Prairie junegrass-Nebraska & $4.67 \mathrm{~cd}$ & $2.27 \mathrm{de}$ & $4.93 \mathrm{def}$ & 2.80 ef \\
\hline Prairie junegrass-Minnesota & $4.40 \mathrm{~cd}$ & $2.13 \mathrm{de}$ & $6.40 \mathrm{a}$ & $3.33 \mathrm{c}$ \\
\hline Perennial ryegrass-'Arctic Green' & $4.27 \mathrm{de}$ & $2.07 \mathrm{e}$ & $3.93 \mathrm{~g}$ & $2.53 \mathrm{f}$ \\
\hline Kentucky bluegrass - 'Park' & $3.67 \mathrm{ef}$ & $2.07 \mathrm{e}$ & $4.40 \mathrm{fg}$ & $2.87 \mathrm{def}$ \\
\hline Kentucky bluegrass - 'Langara' & $3.53 \mathrm{f}$ & $2.07 \mathrm{e}$ & $4.00 \mathrm{~g}$ & $2.80 \mathrm{ef}$ \\
\hline
\end{tabular}

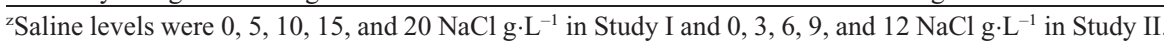

${ }^{y}$ Means in each column followed by the same letter are not significantly different at the $P \leq 0.05$ level.

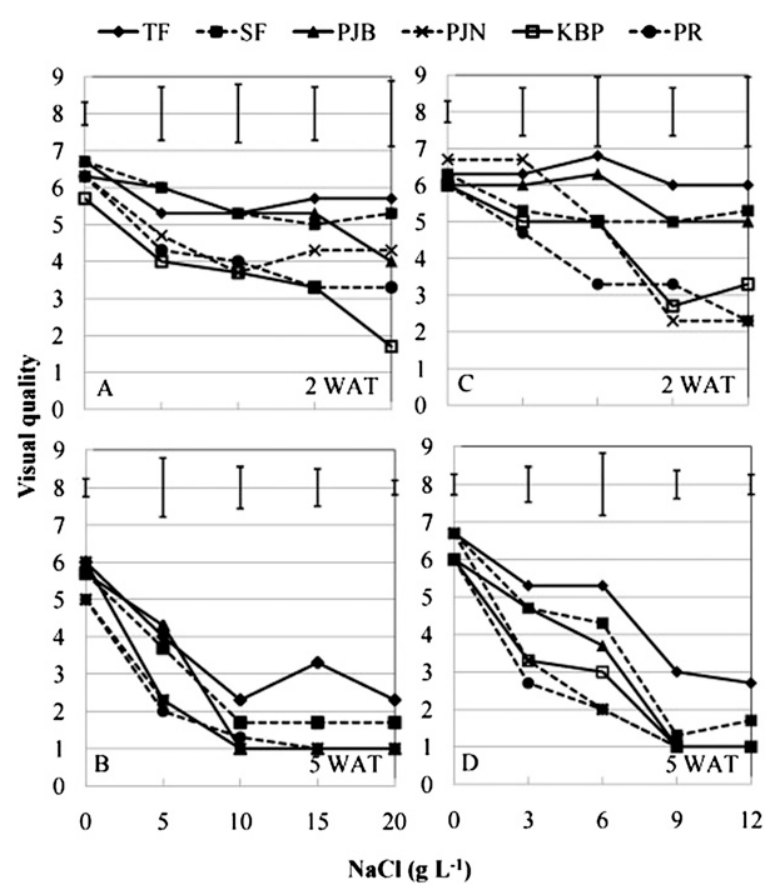

Fig. 3. Visual quality of six representative grasses as influenced by salinity at 2 and 5 weeks after treatment (WAT) in Study I (A-C) and Study II (D-F). The selected grasses included 'Falcon IV' tall fescue (TF), '67135' sheep fescue (SF), 'Barleria' prairie junegrass (PJB), Nebraska prairie junegrass population (PJN), 'Park' kentucky bluegrass (KBP), and 'Arctic Green' perennial ryegrass (PR). Vertical bars represent least significant difference (LSD) at the $P \leq 0.05$ level. 
important than other characteristics such as yield resulting from the aesthetical function of turfgrass. Regrowth rates only need to be at adequate rather than optimal levels under stress conditions. In their evaluation, alkaligrass (Puccinellia nuttalliana), blue grama (Bouteloua gracilis), Idaho bentgrass (Agrostis idahoensis), and 'Barkoel' prairie junegrass all showed reduced growth under severe soil salinity, but alkaligrass was the only grass with adequate quality, indicating relative higher saline tolerance.

In the present study, EL increased as salinity levels increased in the reverse relationship of DW and VQ under saline condition (Fig. 2). Similar to previous studies, EL, DW, and VQ were significantly correlated (Table 5), suggesting that all aforementioned parameters can be used to quantify relative salinity tolerance. However, use of a single parameter may not be sufficient. For example, DW was similar in tall fescue and junegrass-Nebraska populations (Table 3), whereas VQ was significantly higher in tall fescue than in 'Nebraska' junegrass (Table 4) when data were pooled across salinity levels. Similarly, Almansouri et al. (1999) reported no significant differences in relative water content and shoot DW between 'Belikh' (salt-resistant) and 'Cando' (salt-sensitive) durum wheat (T. durum) under saline conditions, but 'Belikh' showed a higher $\mathrm{K} / \mathrm{Na}$ ratio. No grass showed superior salinity tolerance in EL, DW, and VQ when data were pooled across salinity levels (Tables 2-4), which might be the result of the high salinity levels we applied, especially in Study I (up to $20 \mathrm{~g} \cdot \mathrm{L}^{-1} \mathrm{NaCl}$ ). Lunt et al. (1961) reported 50\% of shoot reduction in tall fescue $\mathrm{cv}$. Alta at $160 \mathrm{mEq} \cdot \mathrm{L}^{-1}$ (water $\mathrm{EC}=$ $\left.14 \mathrm{dS} \cdot \mathrm{m}^{-1}\right)$, similar to the moderate saline level $\left(15 \mathrm{~g} \cdot \mathrm{L}^{-1} \mathrm{NaCl}\right)$ in Study I. The highest saline level $\left(20 \mathrm{~g} \cdot \mathrm{L}^{-1} \mathrm{NaCl}\right)$ applied in Study I might have caused severe stress on all grasses, including relatively saline-tolerant ones such as tall fescue. As salinity levels were reduced in Study II, relative salinity tolerance in the grasses were further separated, in which tall fescue and kentucky bluegrass were consistently ranked salt-tolerant and salt-sensitive in EL and VQ (Tables 2 and 4) as shown in other studies (Harivandi et al., 1992; Marcum, 2007). For example, tall fescue provided ac-

Table 5. Correlation coefficients and associated probability levels for electrolyte leakage (EL), tissue dry weight (DW), and visual quality (VQ) across grasses, saline levels, and the duration of saline exposure in Studies I and II.

\begin{tabular}{|c|c|c|c|c|}
\hline \multirow[b]{2}{*}{ Viable } & \multicolumn{2}{|c|}{ Study I ${ }^{z}$} & \multicolumn{2}{|c|}{ Study II } \\
\hline & $\mathrm{DW}^{\mathrm{y}}$ & EL & DW & EL \\
\hline$\overline{\mathrm{EL}}$ & $\begin{array}{l}-0.60 \\
<0.0001\end{array}$ & & $\begin{array}{l}-0.47 \\
<0.0001\end{array}$ & \\
\hline
\end{tabular}

$\begin{array}{llllll}\text { VQ } & 0.68 & -0.72 & 0.57 & -0.71\end{array}$

$<0.0001<0.0001<0.0001<0.0001$

${ }^{\mathrm{z}}$ Saline levels were $0,5,10,15$, and $20 \mathrm{NaCl} \mathrm{g} \cdot \mathrm{L}^{-1}$ in Study I and $0,3,6,9$, and $12 \mathrm{NaCl} \mathrm{g} \cdot \mathrm{L}^{-1}$ in Study II.

${ }^{y}$ Data in EL and DW under saline conditions were expressed as a percentage of the control $(\mathrm{NaCl}=$ $\left.0 \mathrm{~g} \cdot \mathrm{L}^{-1}\right)$. ceptable quality (greater than 5.0) up to 12 $\mathrm{g} \cdot \mathrm{L}^{-1} \mathrm{NaCl}$ by 2 WAT and $6 \mathrm{~g} \cdot \mathrm{L}^{-1} \mathrm{NaCl}$ by 5 WAT (Fig. 3C-D). In contrast, poor appearance of kentucky bluegrass (VQ less than 5.0) was observed at saline levels equal to or higher than $9 \mathrm{~g} \cdot \mathrm{L}^{-1} \mathrm{NaCl}$ at $2 \mathrm{WAT}$ (Fig. 3C); by 5 WAT, VQ decreased to 3.3 at $3 \mathrm{~g} \cdot \mathrm{L}^{-1}$ $\mathrm{NaCl}$ (Fig. 3D). Almansouri et al. (1999) suggested that quantified parameters and final salinity level, besides genotype and environmental conditions, may affect the ranking of relative salinity tolerance in plants.

'Arctic Green' perennial ryegrass showed high salinity tolerance, similar to tall fescue, during germination in the present study (Table 1). However, its relative salt tolerance was comparable to kentucky bluegrass at vegetative growth, contradictory to previous findings that perennial ryegrass was more salt-tolerant (Harivandi et al., 1992; Marcum, 2007). Marcar (1987) reported that relative salinity tolerance of Wimmera (L. rigidum), Italian (L. multiflorum), and perennial ryegrass ranked differently for germinating and mature plants. Differences in perennial ryegrass and kentucky bluegrass cultivars in the studies may also contribute to the inconsistent results, because large variations of salinity tolerance exist in perennial ryegrass and kentucky bluegrass cultivars (Marcum, 2007). Greub et al. (1985) reported that perennial ryegrass cvs. Common and NK 200 and kentucky bluegrass cvs. Park, Pennstar, and Nugget showed similar VQ under saline condition, although the ryegrasses had higher DW than the bluegrasses.

Limited information is available on salinity tolerance on sheep and hard fescue. Sheep fescue cv. 67135 and hard fescue cv. MN-HD1 evaluated in the present study were developed at the University of Minnesota. Although no testing has confirmed its tolerance to salinity stress, ' 67135 ' was originally developed for use on roadsides in northern climates where road salt is a source of physiological stress on turf. Sheep fescue ' 67135 ' showed similar EL, DW, and VQ as tall fescue; however, sheep fescue did not show acceptable VQ under saline conditions at 5 WAT in Study II, whereas tall fescue had acceptable quality at saline levels up to $6 \mathrm{~g} \cdot \mathrm{L}^{-1}$ (Tables 2-4; Fig. 3). Similarly, 'MN-HD1' hard fescue showed a similar salinity tolerance as tall fescue in Study I; however, its VQ was inadequate in Study II (Table 4).

The present study was the first attempt to evaluate the salt tolerance of different populations in prairie junegrass. The results showed that prairie junegrass required average salinity levels of 7.1 and $5.3 \mathrm{~g} \cdot \mathrm{L}^{-1} \mathrm{NaCl}$ to cause $50 \%$ reduction of FGR and DGR, similar to that of kentucky bluegrass (Table 1). Within junegrasses, 'Barleria' was the most salttolerant and 'North Dakota' was the most salt-sensitive based on PSLD, a more sensitive indicator than PSLF (Table 1). Limited variations were observed in all the grasses in vegetative growth except VQ (Tables 2-4; Fig. 3). 'Barleria' junegrass along with tall fescue, sheep fescue, and hard fescue provided acceptable quality at 2 WAT in Study I.
As salinity levels reduced in Study II, all junegrasses except the Nebraska population had adequate quality (greater than 5.0) at 2 WAT, similar to tall fescue and sheep fescue but higher than kentucky bluegrass and perennial ryegrass (Table 4). Furthermore, 'Barleria' junegrass exhibited high VQ (greater than 5.0) under up to $12 \mathrm{~g} \cdot \mathrm{L}^{-1} \mathrm{NaCl}$ at 2 WAT in Study II; so did tall fescue and sheep fescue (Fig. 3C). The decrease of VQ in 'Barleria' junegrass was slower and more gradual than in other prairie junegrass, kentucky bluegrass, and perennial ryegrass as saline exposure extended, although VQ in 'Barleria' junegrass was unacceptable (less than 5.0) at all saline levels at 5 WAT (Fig. 3D). Mintenko and Smith (2001) reported that 'Barkoel' prairie junegrass was tolerant to slight to moderate saline levels (soil EC $=4$ to $8 \mathrm{dS} \cdot \mathrm{m}^{-1}$ ), slightly lower than the susceptibility of tall fescue (soil EC $=6$ to 10 $\mathrm{dS} \cdot \mathrm{m}^{-1}$ ) (Harivandi et al., 1992). The results of this research indicated that salinity tolerance of some junegrass populations increased from germination to the mature stage and its salt tolerance may be further improved through turfgrass breeding because salinity tolerance varied in different junegrass populations.

\section{Literature Cited}

Almansouri, M., J.M. Kinet, and S. Lutts. 1999. Compared effects of sudden and progressive impositions of salt stress in three durum wheat (Triticum durum Desf.) cultivars. J. Plant Physiol. 154:743-752.

Blum, A. and A. Ebrecon. 1981. Cell membrane stability as measure of drought and heat tolerance in wheat. Crop Sci. 21:43-47.

Chen, H.H., Z.Y. Shen, and P.H. Li. 1982. Adaptability of crop plants to high temperature stress. Crop Sci. 22:719-725.

Clark, M.D. and E. Watkins. 2010a. Seed production characteristics of prairie junegrass germplasm accessions. Crop Sci. 50:10571065.

Clark, M.D. and E. Watkins. 2010b. Turfgrass characteristics of prairie junegrass germplasm accessions. Crop Sci. 50:2092-2102.

Dai, J., D.R. Huff, and M.J. Schlossberg. 2009. Salinity effects on seed germination and vegetative growth of green-type Poa annua relative to other cool-season turfgrass species. Crop Sci. 49:696-703.

Dixon, J.M. 2000. Koeleria macrantha (Ledeb.) Schultes $[K$. alpigena Domin, $K$. cristata (L.) Pers. pro parte, $K$. gracilis Pers., $K$. albescens auct. non DC.]. J. Ecol. 88:709-726.

Emmons, R.D. 2000. Turfgrass science and management. 3rd Ed. Delmar, Albany, NY.

Farooq, S. and F. Azam. 2006. The use of cell membrane stability (CMS) technique to screen for salt tolerant wheat varieties. J. Plant Physiol. 163:629-637.

Greub, L.J., P.N. Drolsom, and D.A. Rohweder. 1985. Salt tolerance of grasses and legumes for roadside use. Agron. J. 77:76-80.

Harivandi, M.A., J.D. Butler, and L. Wu. 1992 Salinity and turfgrass culture, p. 207-229. In: Waddington, D.V., R.N. Carrow, and R.C. Shearman (eds.). Turfgrass. Agronomy Monograph No. 32. Madison, WI.

Horst, G.L. and N.B. Beadle. 1984. Salinity affects germination and growth of tall fescue cultivars. J. Amer. Soc. Hort. Sci. 109:419-422. 
Horst, G.L. and N.B. Dunning. 1989. Germination and seedling growth of perennial ryegrass in soluble salts. J. Amer. Soc. Hort. Sci. 114:338-342.

Lunt, O.R., V.B. Younger, and J.J. Oertli. 1961. Salinity tolerance of five turfgrass varieties. Agron. J. 53:247-249.

Marcar, N.E. 1987. Salt tolerance in the genus Lolium (ryegrass) during germination and growth. Aust. J. Agr. Res. 38:297-307.

Marcum, K.B. 1998. Cell membrane thermostability and whole-plant heat tolerance of Kentucky bluegrass. Crop Sci. 38:1214-1218.

Marcum, K.B. 2001. Salinity tolerance of 35 bentgrass cultivars. HortScience 36:374-376.

Marcum, K.B. 2007. Relative salinity tolerance of turfgrass species and cultivars, p. 389-406. In: Pessarakli, M. (ed.) Handbook of turfgrass management and physiology. CRC Press, Boca Raton, FL.

McCarty, L.B. and A.E. Dudeck. 1993. Salinity effects on bentgrass germination. HortScience 28:15-17.

McKernan, D.K., J.B. Ross, and D.K. Tompkins. 2001. Evaluation of grasses grown under low maintenance conditions. Intl. Turfgrass Soc. Res. J. 9:25-32.
Mintenko, A. and R. Smith. 2001. Native grasses vary in salinity tolerance. Golf Course Mgt. 69:55-59.

Mintenko, A.S., S.R. Smith, and D.J. Cattani. 2002. Turfgrass evaluation of native grasses for the northern Great Plains region. Crop Sci. 42: 2018-2024.

Munns, R. 2002. Comparative physiology of salt and water stress. Plant Cell Environ. 25:239-250.

Pammell, L.H., C.R. Ball, and F. Lamson-Scribner. 1901-1904. Grasses of Iowa. Iowa Geol. Survey, Des Moines, IA.

Riordan, T.P. and S.J. Browning. 2003. Buffalograss, Buchloe dactyloides (Nutt.) Engelm, p. 257-270. In: Casler, M.D. and R.R. Duncan (eds.). Turfgrass biology, genetics, and breeding. John Wiley and Sons, Inc., Hoboken, NJ.

Robertson, P.A. 1974. Morphological variation and chromosome numbers of North American populations of Koeleria cristata. Bull. Torrey Bot. Club 101:124-129.

SAS. 2004. SAS 9.1.2 qualification tools user's guide. SAS Institute Inc., Cary, NC.

Seelig, B.D. 2000. Salinity and sodicity in North Dakota Soils. 5 Jan. 2011. <http://www.ag.ndsu. edu/pubs/plantsci/soilfert/eb57-1.htm>.
Soovali, P. and A. Bender. 2006. The occurrence of powdery mildew on crested hairgrass in different growing conditions. Agron. Res. 4:385388.

Su, K., D.J. Bremer, S.J. Keeley, and J.D. Fry. 2007. Effects of high temperature and drought on a hybrid bluegrass compared with Kentucky bluegrass and tall fescue. Crop Sci. 47:21522161.

Sullivan, C.Y. and W.M. Ross. 1979. Selecting for drought and heat resistance in grain sorghum, p. 263-281. In: Mussell, H. and R. Staples (eds.). Stress physiology in crop plants. John Wiley \& Sons, New York, NY.

Tabaei-Aghdaei, S., P. Harrison, and R.S. Pearee. 2000. Expression of dehydration-stress related genes in crown of wheat grass species having contrasting acclimation to salt, cold and drought. Plant Cell Environ. 23:561571.

Wang, S. and Q. Zhang. 2010. Responses of creeping bentgrass to salt stress during in vitro germination. HortScience 45:1747-1750.

Zhang, Q., S. Wang, and K. Rue. 2011. Salinity tolerance of 12 turfgrasses in three germination media. HortScience 46:651-654. 